\title{
Mast Cell Neoplasm
}

National Cancer Institute

\section{Source}

National Cancer Institute. Mast Cell Neoplasm. NCI Thesaurus. Code C9295.

A heterogeneous group of disorders characterized by the abnormal growth and accumulation of mast cells in one or more org an systems. Recent data suggest that most variants of mast cell neoplasms are clonal disorders. (WHO, 2001) 